\title{
Pelatihan Pendidikan Seks Anak Usia Dini pada Kader 'Aisyiyah Ranting Pandeyan Kecamatan Umbulharjo
}

\author{
Ellyda Rizki Wijhati ${ }^{1}$, Suharni ${ }^{2}$ \\ ${ }^{1,2}$ Universitas 'Aisyiyah Yogyakarta \\ Email: ewijhati@ymail.com ${ }^{1}$
}

\begin{abstract}
ABSTRAK
Usia 0 - 6 tahun merupakan masa "golden age" yang sangat penting dan menentukan kualitas hidup anak kelak. Dewasa ini banyak terjadi kekerasan seksual dengan korban anak, penyebabnya antara lain karena lemahnya pengawasan orang tua dan belum optimalnya pendidikan seks pada anak. Anak sangat rentan menjadi korban kekerasan seksual karena dianggap tidak berdaya untuk melakukan perlawanan terhadap pelaku. Pendidikan seks merupakan upaya yang dapat dilakukan untuk mencegah terjadinya kekerasan seksual, namun masih banyak masyarakat yang memiliki pandangan bahwa memberikan pendidikan merupakan hal yang tabu, kurang penting, anak akan mendapatkan pengetahuan itu disekolah sehingga banyak orang tua yang tidak memberikan pendidikan seks pada anak. Akibatnya anak tidak mempunyai pengetahuan yang cukup tentang kesehatan seksual dan tidak dapat melindungi dirinya jika mengalami kekerasan atau pelecehan seksual. Kegiatan pelatihan diharapkan dapat menambah pengetahuan dan kesadaran kader akan pentingnya memberikan pendidikan seks pada anak. Pelaksanaan pelatihan dilakukan selama 2 kali pertemuan dengan durasi 5 jam. Pertemuan pertama membahas tentang urgensi memberikan pendidikan seks pada anak dan Focus Group Disscussion (FGD). Pertemuan kedua membahas tentang cara- cara memberikan pendidikan seks serta materi yang harus disampaikan pada anak tentang kesehatan reproduksinya, diskusi tanya jawab, serta pelatikan kader kesehatan produksi. Hasil pelatihan ada kenaikan tingkat pengetahuan dan perubahan persepsi tentang pendidikan seks pada anak serta terbentuknya kader kesehatan reproduksi.
\end{abstract}

Kata Kunci: Anak, kekerasan seksual, Pendidikan seks, Usia Dini.

\section{ABSTRACT}

Age 0-6 years is a period of "golden age" very important and determine the quality of life of children later. Nowadays there are many sexual violence with child victims, caused by weakness of parental supervision and not optimal of sex education in children. Children are particularly vulnerable to being sexually assaulted as being powerless to take action against the perpetrators. Sex education is an effort that can be done to prevent the sexual violence, but many parent assume that sex education is a taboo, less important, children will get that knowledge in school so many parents who do not provide sex education in children. As a result, the child does not have sufficient knowledge about sexual health and cannot protect himself if he experiences violence or sexual harassment. Training activities are expected to increase the knowledge and awareness of cadres of the importance of providing sex education in children. Implementation of the training is done for 2 meetings with a duration of 5 hours. The first meeting discussed the urgency of providing sex education in children and Focus Group Discussions (FGD). The second meeting discussed ways 
of providing sex education and materials to be conveyed to children about their reproductive health, question and answer discussion, and production healthcare cadres. The results of training there is an increase in the level of knowledge and changes in perception of sex education in children and the establishment of reproductive health cadres.

Keywords: Children, Early Age, Sex Education, Sexual Violence

\section{PENDAHULUAN}

Tingginya angka kekerasan seksual anak merupakan hal yang sangat memprihatinkan, pelaku kekerasan sering dilakukan oleh orang-orang terdekat atau bahkan dilakukan oleh keluarga korban sendiri. Meningkatnya kasus kekerasan seksual pada anak merupakan bukti kurangnya pengetahuan anak mengenai pendidikan seks yang seharusnya sudah mereka peroleh dari tahun pertama oleh orang tuanya. Pandangan masyarakat mengenai pendidikan seks yang masih menganggap tabu menjadi salah satu penyebab anak tidak mendapatkan pendidikan seksual yang benar.

Pendidikan seks merupakan bentuk kepedulian orang tua terhadap masa depan anak dalam menjaga apa yang telah menjadi kehormatannya, terlebih bagi seorang perempuan. Pendidikan seks sangat penting diberikan secara dini mengingat banyaknya kasus tindak kekerasan seksual terhadap anak dan remaja. Fenomena yang terjadi di lapangan justru orang tua bersikap apatis dan pasif memberikan pendidikan seks pada anak.

Pandangan masyarakat sepertinya masih terlalu sempit dalam mengartikan seks yang hanya dianggap sebagai aktivitas mesum hingga ke hal-hal yang lebih intim. Makna seks sebenarnya menurut Kamus Besar Bahasa Indonesia (KBBI) adalah jenis kelamin, maksudnya disini adalah jenis kelamin yang membedakan pria dan wanita secara biologis. Namun karena kurangnya pengetahuan para orang tua menjadikan pendidikan seks belum diajarkan kepada anak bahkan sebagian besar remaja pun tidak memperoleh pengajaran tentang pendidikan seks dari keluarga terutama dari orang tuanya sehingga mereka mendapatkan informasi yang tidak tepat bahkan cenderung menjerumuskannya untuk melakukan apa yang mereka temukan dari informasi yang tidak bertanggung jawab tersebut.

Berdasarkan studi pendahuluan di Kelurahan Pandeyan merupakan wilayah padat penduduk, dengan mayoritas pendidikan keluarga SMP dan social ekonomi menengah kebawah. Banyak orang tua balita/ anak usia Sekolah Dasar yang belum tahu tentang arti penting memberikan pendidikan seks sedini mungkin, bahkan terdapat orang tua yang menganggap bahwa dengan sendirinya anak akan mengetahui perihal seksual saat sudah dewasa. 


\section{METODE PELAKSANAAN}

Kegiatan pelatihan tentang pendidikan seks anak usia dini di Kelurahan Pandeyan Kecamatan Umbulharjo dilaksanakan sejak minggu keempat januari hingga minggu pertama maret 2017. Kegiatan dimulai dengan melakukan pendekatan kepada ketua ranting, dan kader 'Aisyiyah. Setelah mendapatkan izin untuk mengadakan pelatihan, pelaksana melakukan pendekatan pada pimpinan ranting 'Aisyiyah Pandeyan Kecamatan Umbulharjo, pendekatan dilakukan 1 minggu. Ketua dan anggota sangat antusias dan tertarik dengan rencana program penyuluhan tentang pendidikan seks anak usia dini, mengingat dewasa ini banyak sekali kasus kekerasan seks yang dialami anak. Pelaksaan kegiatan dilakukan sebanyak 3 kali:

1. Kegiatan Pertama

Pretest tentang urgensi memberikan pendidikan seks, penyuluhan tentang urgensi memberikan pendidikan seksual pada anak dan diakhiri dengan Focus Group Discussion untuk menginventaris permasalahan yang sering dihadapi orang tua khusunya ibu saat memeberikan pendidikan seks.

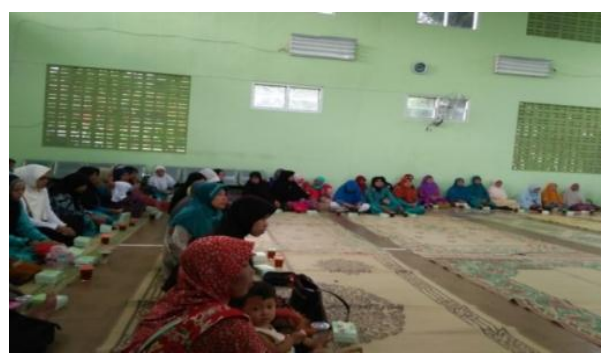

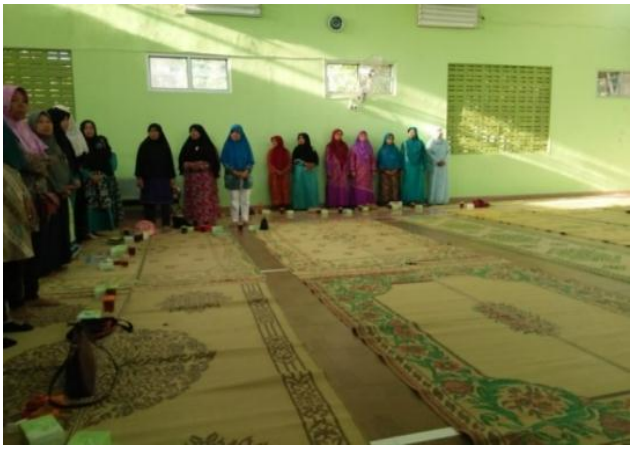

2. Kegiatan Kedua

Pelatihan Cara memebrikan Pendidikan Seks sesuai usia anak, Diskusi dan Tanya jawab serta pelantikan kader kesehatan reproduksi dengan penyematan PIN.

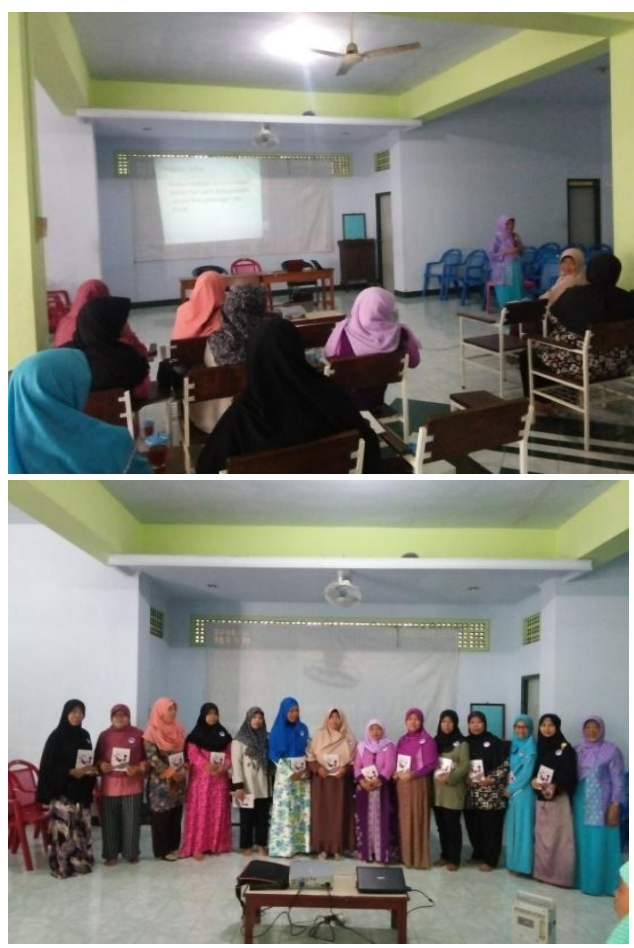

3. Kegiatan Ketiga

Posttest tentang urgensi memberikan pendidikan seks dan evaluasi pelaksanaan pemberian pendidikan seks. 


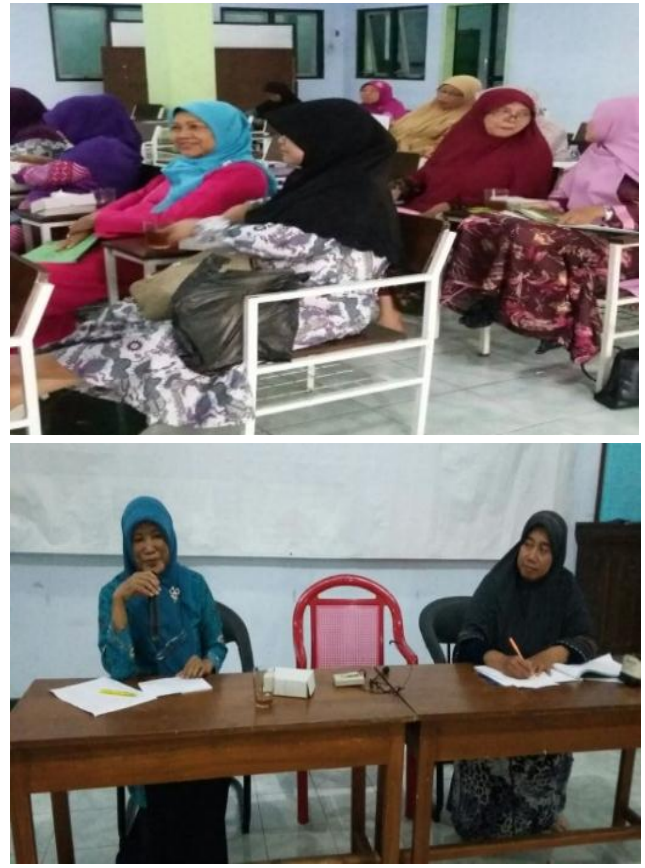

\section{HASIL DAN PEMBAHASAN}

Target dalam pelatihan adalah ibu-ibu anggota ranting 'Aisyiyah Pandeyan. Pelatihan Pendidikan Seks Anak Usia Dini, dilakukan 3 kali. Kegiatan pertama dilaksanakan pada hari Ahad, 29 Januari 2017 pukul 15.00-17. 30 WIB bertempat di Balai RW 8 Kelurahan Pandeyan Kecamatan Umbulharjo dengan jumlah 38 peserta. Kegiatan pertama berisi materi tentang "Urgensi Pendidikan Seks Anak Usia Dini" dengan tujuan memberikan gambaran pada peserta penyuluhan tentang arti penting memberikan pendidikan seks sedini mungkin pada anak sebagai upaya pencegahan kekerasan seksual bagi anak. Sebelum itu peserta penyuluhan diberikan pertanyaan pretest terlebih dahulu. Setelah pernyuluhan selesai, acara dilanjutkan dengan Focus Group
Discussion (FGD) untuk mengumpulkan permasalahan yang dialami perserta penyuluhan dalam memberikan pendidikan seks pada anak.

Sebagian besar peserta masih enggan memberikan pendidikan seks pada anak karena masih dianggap tabu karena berarti mengajakran anak mengetahui hubungan suami istri, saat dewasa kelak secara otomatis anak akan paham akan seksualitas. Hal tersebut disebabkan karena kurangnya pengetahuan orang tua tentang tujuan pemberian pendidikan seks. Sesuai dengan pendapat Chomaria (2011) yang menyatakan bahwa anggapan yang tidak tepat tentang pendidikan seks menyebabkan orang tua enggan memberikan pendidikan seksual pada anak.

Menurut Adi
pendidikan seks adalah usaha
pemberian informasi kepada anak
tentang kondisi fisik sebagai
perempuan dan laki- laki dan
konsekuensi psikologis yang
berkaitan dengan kondisi tersebut. Pendidikan seks terdiri dari organ reproduksi, kehamilan, tingkah laku seksual, alat kontrasepsi, kesuburan, menopause serta penyakit kelamin. Dengan memberikan pendidikan seks sedini mungkin pada anak, makan orang tua dapat mencegah pergaulan bebas dan dapat mencegah anak menjadi korban pelevehan seksual (Priyatna, 2015).

Kegiatan kedua diadakan pada hari minggu, 12 Februari 2017 
pukul 08.00-11.00 WIB bertempat di Masjid Baiturahman Pandeyan Umbulharjo diikuti 13 peserta. Pelatihan kedua berisi materi tentang "Cara memberikan pendidikan seks dan cara mencegah kekerasan seksual pada anak". Pada acara kedua dibuka sesi tanya jawab, dan diskusi tentang hasil FGD yang dilakukan pada penyuluhan pertama. Diskusi berjalan hangat dan peserta sangat antusias dengan materi yang diberikan. Acara kedua diikuti masing-masing perwakilan kader tiap RW yang bersedia untuk dilantik menjadi kader kesehatan.

Ada acara pelantikan kader kesehatan reproduksi dilaksanakan pada akhir kegiatan untuk menumbuhkan rasa semangat pada ibu- ibu peserta pelatihan untuk menyebarluasan pentingnya memberikan pendidikan kesehtan reproduksi pada anak dalam bentuk pendidikan seks sedini mungkin sebagai upaya pencegahan pelecehan seksual pada anak yang dewasa ini sangat marak dan makin memprihatinkan. Pelantikan kader kespro dilakukan dengan pemasangan PIN oleh ketua ranting 'aisyiyah beserta ketua team pengabdian masyarakat (Suharni., M.Kes).

Acara ketiga berupa evaluasi kegiatan pelatihan kader kesehatan reproduksi yang diselenggarakan pada hari, Kamis 2 Maret 2017 pukul 15.00- 16.30 WIB yang bertempat di Masjid Baiturrahman Pandeyan. Dari hasil evaluasi kader kespro telah menyampaikan materi pelatihan kepada ibu-ibu lainnya terutama yang memiliki anak dibawah usia 15 tahun, sebagian kader sudah mulai mengidentifikasi permasalahan kespro yang berhubungan dengan anak dan pemberian pendidikan seks. Dari hasil posttest pelatihan ada kenaikan pengetahuan ibu- ibu kader tentang pentingnya memberikan pendidikan seks.

\section{SIMPULAN}

Berdasarkan hasil kegiatan pengabdian masyarakat dapat disimpulkan bahwa:

1. Ada perubahan Persepsi kader 'Aisyiyah Ranting Pandeyan tentang pendidikan seks yang dulunya dianggap tabu, menjadi sesuatu yang penting dan harus sesegera mungkin diberikan pada anak mengingat maraknya kasus pelecehan seksual pada anak.

2. Pengetahuan kader tentang pentingnya memberikan pendidikan seks anak usia dini bertambah ditandai dengan peserta penyuluhan dapat menjawab pertanyaan dengan benar.

3. Kader sangat antusias mengikuti jalannya acara penyuluhan dan banyak pertanyaan yang diberikan oleh peserta tentang pemberian pendidikan seks anak usia dini.

\section{DAFTAR PUSTAKA}

Andika, Alya. 2010. Ibu, Dari Mana Aku Lahir. Yogyakarta: Pustaka Grhatama 
Chomaria, N. 2012. Pendidikan Seks untuk anak. Solo: Aqwam Jembatan Ilmu

John W. Santrock. 2011. Masa Perkembangan Anak. Jakarta: Salemba Humanika

Madan, Yusuf. 2004. Sex Education For Children (Panduan Islam Orang Tua dalam Pendidikan Seks untuk Anak). Bandung: Hikmah PT Mizan Publika.
Priyatna, A. \& Uci, O.S. De, 2015. Pelecehan Seksual Anak Cegah Sebelum Terjadi, Jakarta: PT Elex Media Komputindo kelompok Gramedia.

Roqib. 2008. Pendidikan Seks pada Anak Usia Dini. Jurnal Pemikiran Alternatif Pendidikan. Vol. 13 No. 2. P3M STAIN Purwokerto.

Adi. J. Erwin, 2005. Pendidikan Seks. Yogyakarta: Curosita. 